\title{
Designing the Concrete Mix Design in order to Determine the Deviation Value of the Two Concrete Compressive Test Instruments (Pressure Test and Hammer Test)
}

\author{
Asmadi \& Susi Haryani \\ Jurusan Teknik Sipil Politeknik Negeri Pontianak \\ Jalan Jenderal Ahmad Yani Pontianak Tenggara, Kota Pontianak 78124 \\ Email: asmadiptk123@gmail.com
}

\begin{abstract}
The role of concrete material in building structures is a very important, in the other word almost all of structural building use concrete components. Using this research, we try to ascertain how big the deviation results from the two tools. Through laboratory research that is examined from the physical coarse aggregate material, fine aggregate, we get the job mix concrete formula. the quality of the concrete that we design is concrete $K-200 \mathrm{~kg} / \mathrm{cm} 2$. from the results of our job mix, the proportion of the concrete mixture for $1 \mathrm{~m} 3$ of concrete is as follows cement $351.85 \mathrm{~kg}$, sand $780.42 \mathrm{~kg}$, crushed stone $1077.73 \mathrm{~kg}$, water $142.34 \mathrm{~kg}$, then made as many as 15 pieces of cube specimens. Then for the finished structural test object, a building is made from the structure of the foundation, loop beams, columns, floor beams and floor slabs. When casting is carried out, the making of concrete cube specimens is taken back, respectively, the number of foundation test objects is 3 concrete cubes, 3 sloop blocks of concrete cubes, 3 columns, 3 beams and 3 floor plates. The average test results of these test tools are as follows: the pressure test using the concrete pressure test device is $211 \mathrm{~kg} / \mathrm{cm}^{2}$, and the test result using the concrete hammer test is $195 \mathrm{~kg} / \mathrm{cm}^{2}$.
\end{abstract}

Keywords: Mix Design concrete, Concrete Compressive Test Instruments, Deviation Value, presure test conreate, hummer tes concreate

\section{Perancangan Mix Design Conreate dalam rangka Menentukan Nilai Deviasi dari Dua Alat Uji Tekan Beton (Pressure Test Conreate) dengan Alat Uji Tekan Beton Hummer Test Conreate}

\begin{abstract}
Abstrak: Material beton peranannya dalam bangunan struktur adalah merupakan komponen yang sangat penting, dalam artian hampir tidak ada bangunan struktur yang tidak menggunakan komponen beton. Melalui penelitian ini kami mencoba memastikan seberapa besar hasil penyimpangan atau deviasi nilai dari kedua alat. Melalui penelitian di laboratorium yang diperiksa dari fisik bahan agregat kasar, agregat halus maka kami mendapatkan formula jobmix concreate. Mutu beton yang kami rancang adalah beton K-200 kg/cm2. Dari hasil jobmix kami dapat proporsi campuran beton untuk $1 \mathrm{~m} 3$ beton sebagai berikut; semen $351.85 \mathrm{~kg}$, pasir $780,42 \mathrm{~kg}$, batu pecah $1077,73 \mathrm{~kg}$, air $142.34 \mathrm{~kg}$, kemudian dibuat benda uji kubus sebanyak 12 buah. Hasil pengujian rata- rata dari masing- masing alat uji tersebut adalah sebagai berikut: uji tekan menggunakan alat uji tekan presure test conreate adalah $211 \mathrm{~kg} / \mathrm{cm}^{2}$, dan hasil uji pengujian menggunakan alat uji hammer test concreate sebesar $195 \mathrm{~kg} / \mathrm{cm}^{2}$.
\end{abstract}

Kata kunci: mixdesign concreate, Concrete Compressive Test Instruments, nilai deviasi, pressure test conreate, hummer tes concreate

Beton adalah campuran yang terdiri dari agregat kasar dan halus, ditambah semen por- land sebagai bahan perekat, air sebagai bahan katalisator pereaksi kimia, dan bahan aditif jika 
diperlukan diaduk hingga homogen dan biarkan dalam waktu tertentu maka dapat menjadi suatu bahan yang kompak/ keras dan mempunyai kekuatan tahan seperti yang kita rencanakan. Material beton untuk konstruksi sebagian besar menggunakan material agregat kasar seperti batu pecah, batu sungai/ kerikil dan material lainnya yang dianggap mempunyai spesifikasi kekerasan dan ukuran serta bentuk butir yang memadai dapat dipakai sebagai bahan agregat kasar. Sedangkan material agregat halus yang lebih umum digunakan adalah pasir sungai dan material lainnya seperti batu splite/ debu batu, biji besi dan material agregat halus lainnya yang mempunyai spesifikasi bentuk dan ukuran yang dapat digunakan sebagai agregat halus. Sedangkan bahan perekat yang digunakan adalah sejenis semen portland dengan berbagai tipe, yaitu tipe 1 - tipe 5 dengan standar semen yang ada di Indonesia yaitu SNI. Agar semen dapat berfungsi sebagai bahan perekat maka digunakan air sebagai bahan bahan kalisator. Tanpa air semen tidak bisa berfungsi sebagai bahan perekat kerena air adalah bahan katalisator untuk pereaksi. Air yang digunakan sebagai bahan campuran beton adalah adalah air dengan dengan kualitas baik yang tidak mengandung zat organik, zat asam, zat garam dan zat lainnya yang dapat merusak mutu beton.

Kualitas penggunaan bahan material beton seperti disebutkan di atas sangat mempengaruhi kualitas mutu beton. Semakin baik kualitas material/ bahan beton yang digunakan tentunya akan mengahasilkan kualitas mutu beton yang baik pula, walaupun sesungguhnya kualitas mutu beton juga ditentukan olah metode pelaksaaan pekerjaan beton di lapangan. Metode pelaksaan pekerjaan beton meliputi; kondisi bekesting, pencampuran adukan, lama pengadukan, kondisi pengangkutan beton segar, kondisi pada saat pengecoran dan lama pemadatan, pemeliharaan beton pada saat pengerasan serta kondisi cuaca pada saat pengecoran.

Baik atau tidaknya kualitas mutu beton yang sudah jadi atau mengeras yang digunakan untuk konstruksi bangunan dapat diukur dan diuji dengan dua metode pengujian, yaitu dengan alat uji tekan beton presure test concreate dan alat uji tekan beton hummer test concreate. Pengujian menggunakan alat uji presure test conreate dimana sampel dengan ukuran berbentuk kubus $15 \mathrm{~cm} \times 15 \mathrm{~cm} \times 15 \mathrm{~cm}$ beton atau dibuat benda uji silinder ukuran dimeter $10 \mathrm{~cm}$ dan tinggi $30 \mathrm{~cm}$. Benda uji tersebut diuji pada saat beton berumur tujuh hari, 14 hari, 21 hari dan 28 hari dimana pengujian dilaksanakan di dalam laboratorium konstruksi beton. Sedangkan pengujian dengan menggunakan metode hummer test concreate sampel diambil langsung ditempat berdirinya konstruksi bangunan yang dianggap sudah jadi. Pengujian tersebut dilaksanakan di lapangan atau dilokasi berdirinya bangunan.

Dari kedua metode pengujian ini menurut sebagian ahli berpendapat hasil pengujian menggunakan hummer test concreate belum terlalu dianggap akurat, dikarenakan kekerasan beton hanya terbaca pada permukaannya beton saja dan tidak bisa membaca sampai pada inti atau pusat titik berat kekerasan beton. Pengujian yang paling tepat adalah menggunakan kuat tekan beton dengan alat presure test concreate. Akan tetapi pada kenyataannya pengujian menggunakan alat hammer test conretate ini masih tetap dilakukan dan bahkan dilakukan oleh para pemeriksa di lapangan seperti oleh pihak pemeriksa/supervisi dari ke PU-an, pihak investigasi kejaksaan dan pihak kepolisian serta pihak pemeriksa (investigator) lainnya pada saat sedang melakukan investigasi pekerjaan dilapangan. Metode pemeriksaan mutu beton dengan alat hammer test concreate dianggap 
metode yang paling praktis dan tidak merusak benda kerja.

Melalui penelitian ini kami mencoba membuka tabir perselihan hasil nilai (deviasi) pengujian dari kedua metode yang dianggap menjadi perbedaan oleh para ahli. Dari penelitian ini kami akan mencari seberapa selisih nilai hasil pengujian menggunakan alat presure test concrete dengan hummer test concreate yang mengasilkan deviasi atau penyimpangan nilai tekan beton.

Didalam penelitian ini sampel untuk benda uji direncanakan dengan mutu beton $\mathrm{K}$ $200 \mathrm{~kg} / \mathrm{cm} 2$ dengan terlebih dahulu membuat rencana jobmix formula beton yang dilakukan di laboratorium. Setelah itu benda uji dibentuk kubus dengan ukuran standar pengujian yaitu berukuran $15 \mathrm{~cm} \times 15 \mathrm{~cm} \times 15 \mathrm{~cm}$ dengan jumlah benda uji sebanyak 12 buah benda dengan umur pengujian umur 7 hari, umur 14 hari dan umur 21 hari, ukur 28 hari masing- dari tiap umur sebanyak 3 buah. Sampel untuk benda uji kubus beton juga dibuat pada saat pengecoran di lapangan berjumlah 12 buah yang terdiri dari 3 buah benda uji pelat pondasi, 3 buah benda uji balok sloop, 3 buah benda uji kolom dan 3 buah benda uji balok dan kantai. Untuk nilai uji tekan pressure test concreate benda uji yang dipakai adalah hasil benda uji kubus beton pada saat pengecoran. Sedangkan penggujian menggunakan metode hummer terst concreate sampel benda dibuat seperti pada saat tim pemeriksa atau tim investigator dalam melakukan pemeriksaan lapangan, dimana benda uji dirancang seperti kontruksi banguan yang sesungguhnya konstruksi beton bertulang dan didirikan di lapangan dengan mutu beton $\mathrm{K}-200 \mathrm{~kg} / \mathrm{cm} 2$. Benda uji yang dibuat adalah dimulai dari konstruksi pondasi, balok sloop, kolom dan pelat lantai beton bertulang. Pengujian dilakukan pada saat umur beton sudah mencapai $100 \%$ yaitu 28 hari dan bahkan lebih dari umur 28 hari. Pada prinsipnya pengujian menggunakan alat uji tekan hummer test conceate persis apa yang dilakukan oleh tim pemeriksa/ investigator pada saat melakukan investigasi terhadap bangunan konstruksi di lapangan. Kesimpulan dari penelitian ini adalah untuk mencari nilai perbedaan (deviasi/ penyimpangan) nilai dari kedua metode pengujian tersebut, dimana nilai tersebut selama ini menjadi perbedaan para ahli.

\section{METODE}

Penelitian ini dilakukan pada dua lokasi pekerjaan yaitu dilakukan didalam ruangan laboratorium Jurusan Teknik Sipil Dan Perencanaan dengan uji fisik material beton, dan lokasi kedua dilakukan diluar ruangan yaitu di samping gedung bengkel sipil dengan pembuatan konstruksi tempat penyimpanan limbah kayu.

Proses awal dari penelitian ini adalah melakukan pengujian fisik material beton yang akan dipakai dalam pembuatan benda uji. tujuan dari penggujian ini adalah untuk mendapatkan nilai yang tepat dalam merencanakan Job mixdisign conrcreate. Dari jobmix design didapat takaran yang mendekati dalam merencanakan mutu beton dalam hal ini beton $\mathrm{K}-200 \mathrm{Kg} / \mathrm{cm}^{2}$.

Adapun pekerjaan yang dilaksanakan di dalam laboratorium ini adalah sebagai berikut: Pengujian material agregat (batu pecah) didapat hasil sebagai berikut:

- Berat jenis bolk/ oven batu pecah $=2,62$.

- Berat jenis SSD =2,63.

- Berat jenis AAP =2,64.

- Penyerapan $=0,30$.

- Berat isi =1,49 kg/liter. 


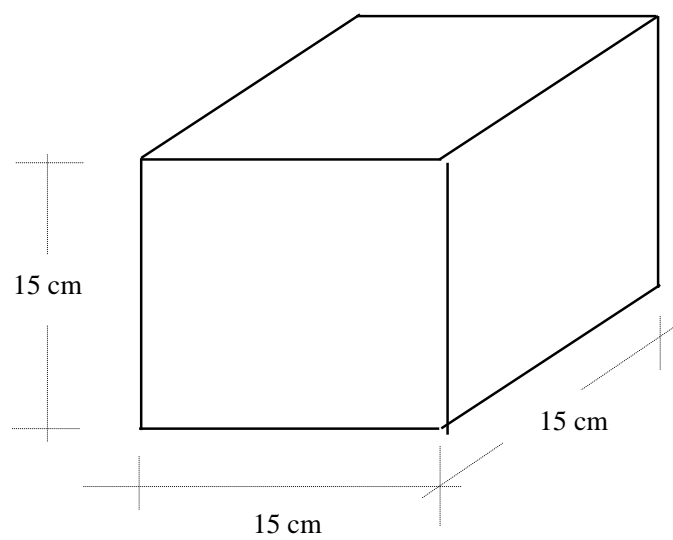

Gambar 1. Bentuk Benda Uji Kubus Beton

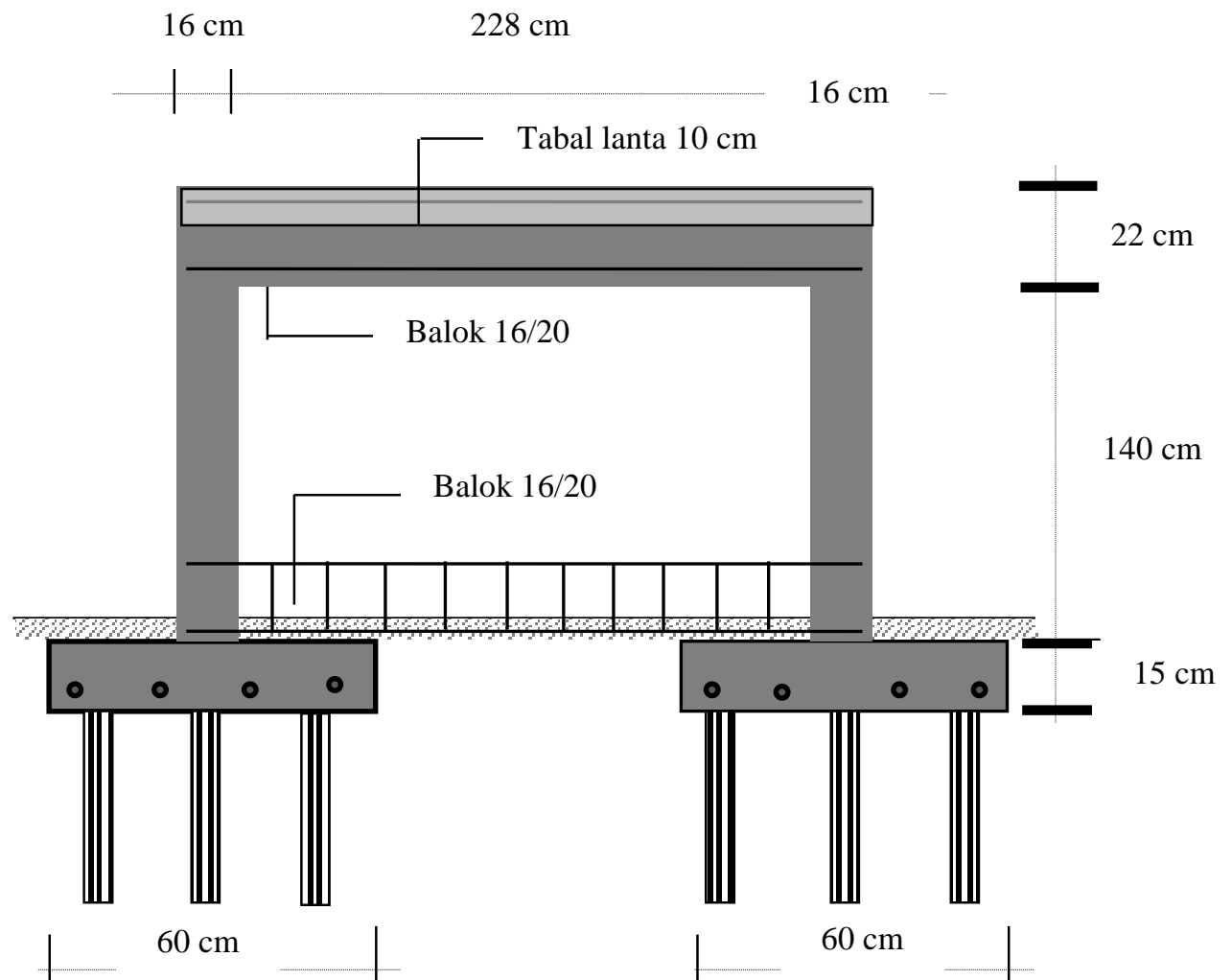

Gambar 2. Bentuk Benda Uji Struktur Bangunan Gedung Pot. A-A

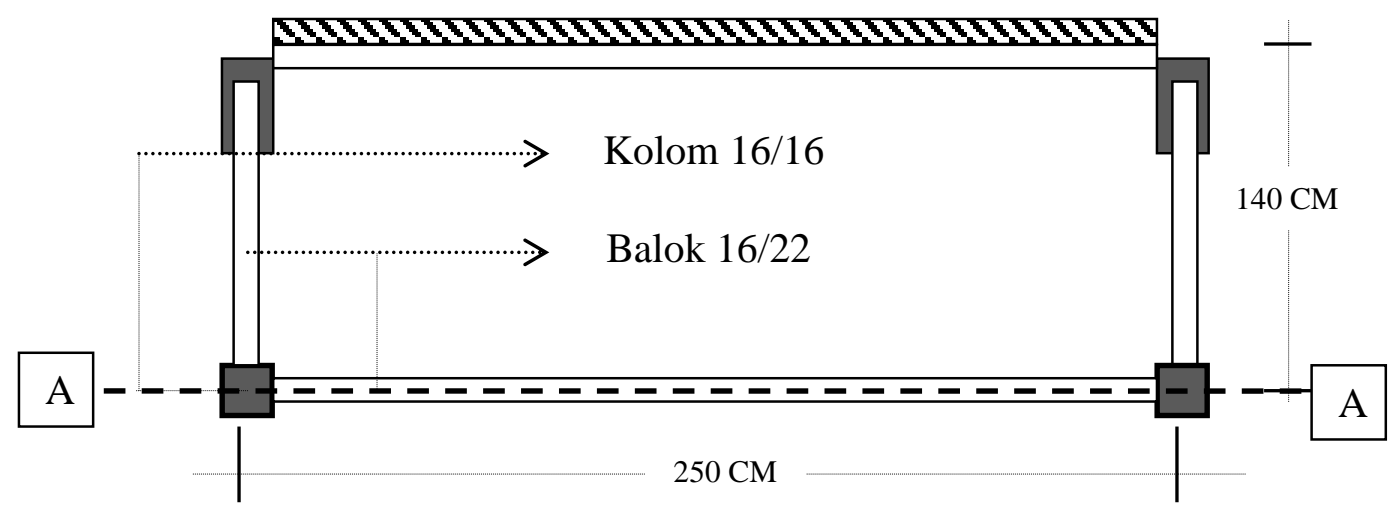

Gambar 3. Denah Struktur Bangunan Benda Uji 

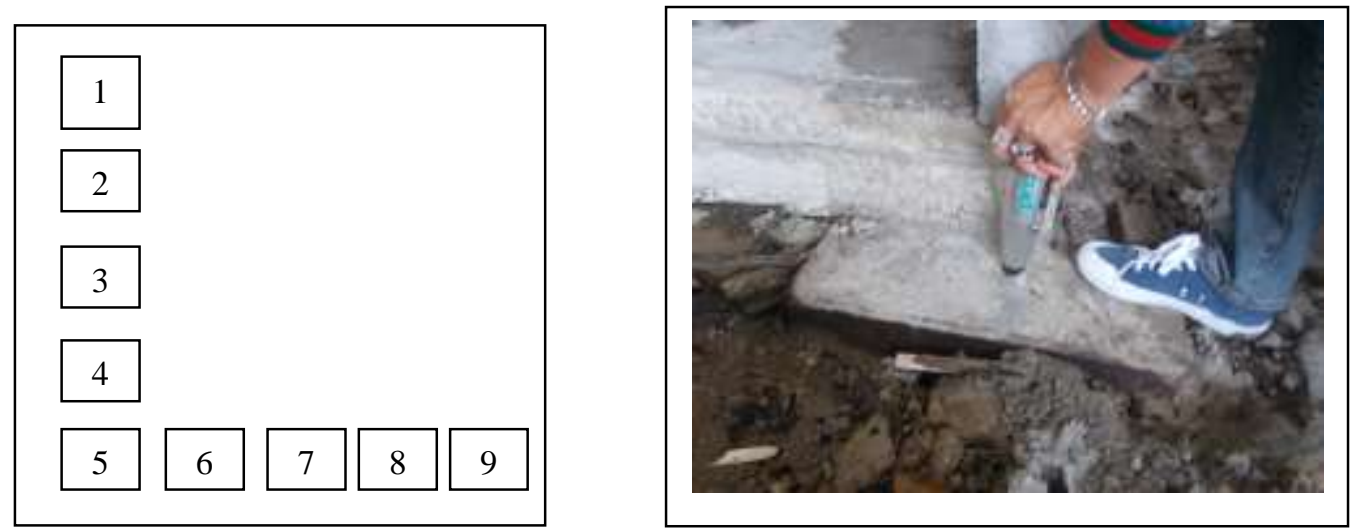

Gambar 4. Pengujian Tekan Beton Pelat Pondasi menggunakan Hummert Test Conreate
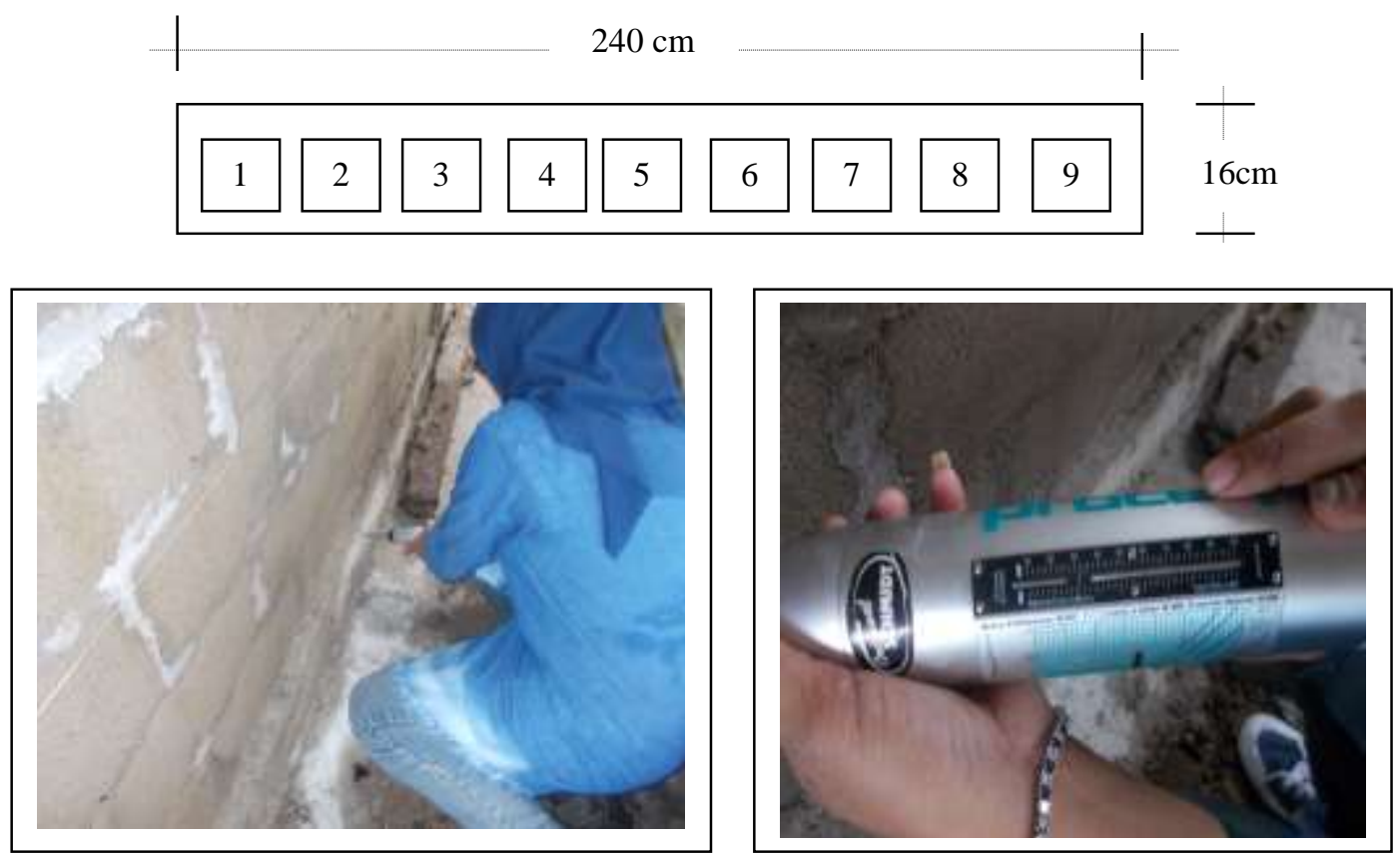

Gambar 5. Pengujian Tekan Beton Balok sloop menggunakan Hummert Test Conreate
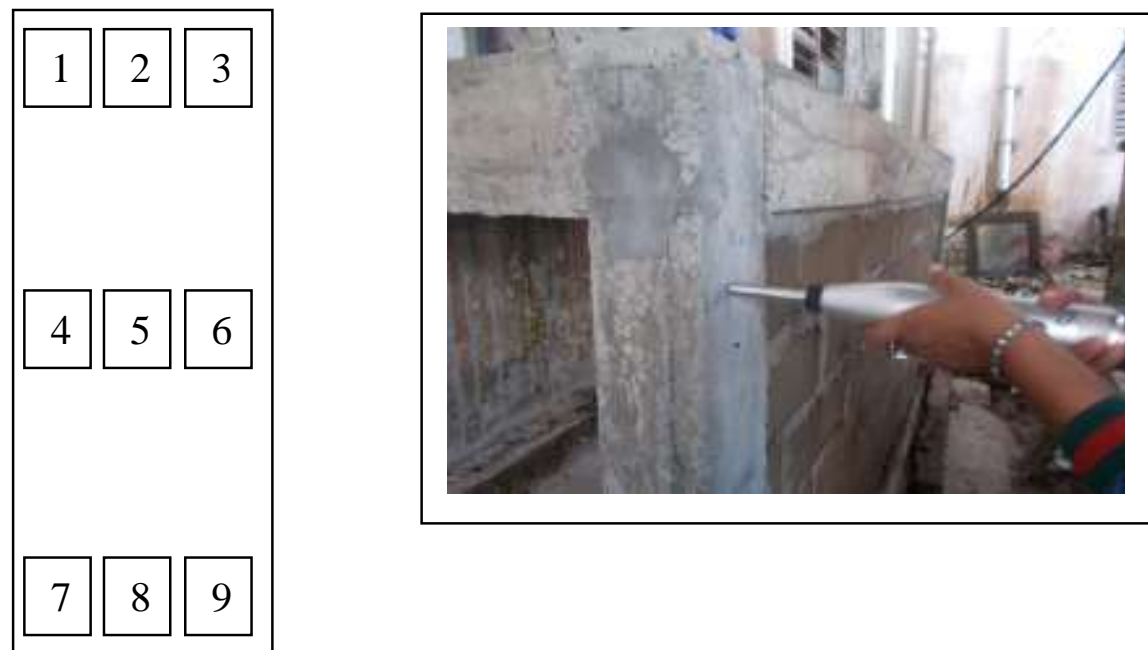

Gambar 6. Pengujian Tekan Beton Kolom Menggunakan Hummert Test Conreate 


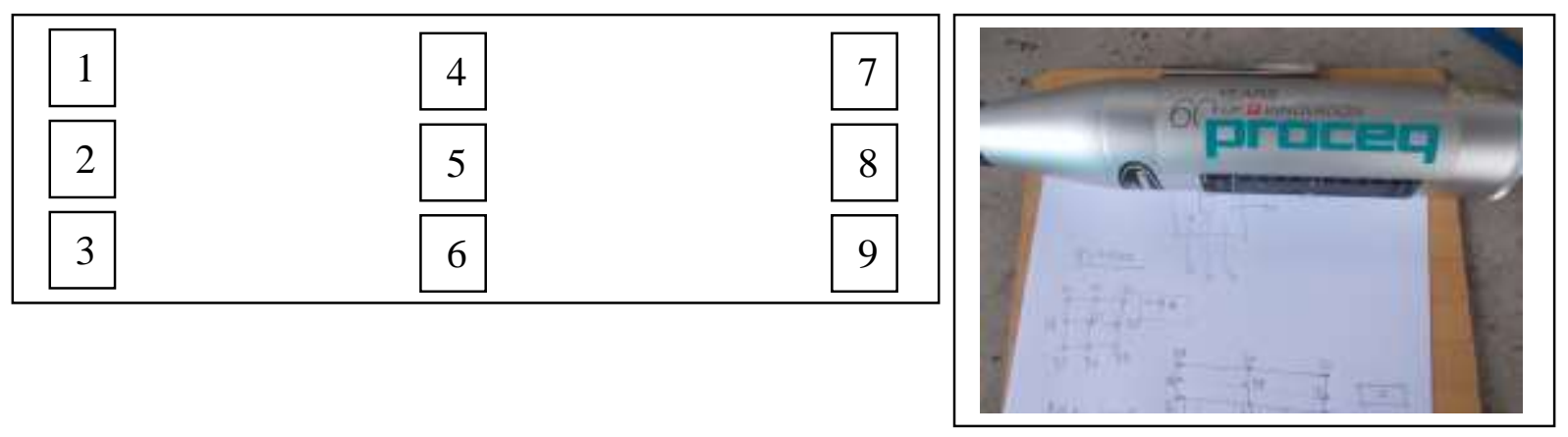

Gambar 7. Pengujian Tekan Beton Balok dan Lantai menggunakan Hummert Test Conreate

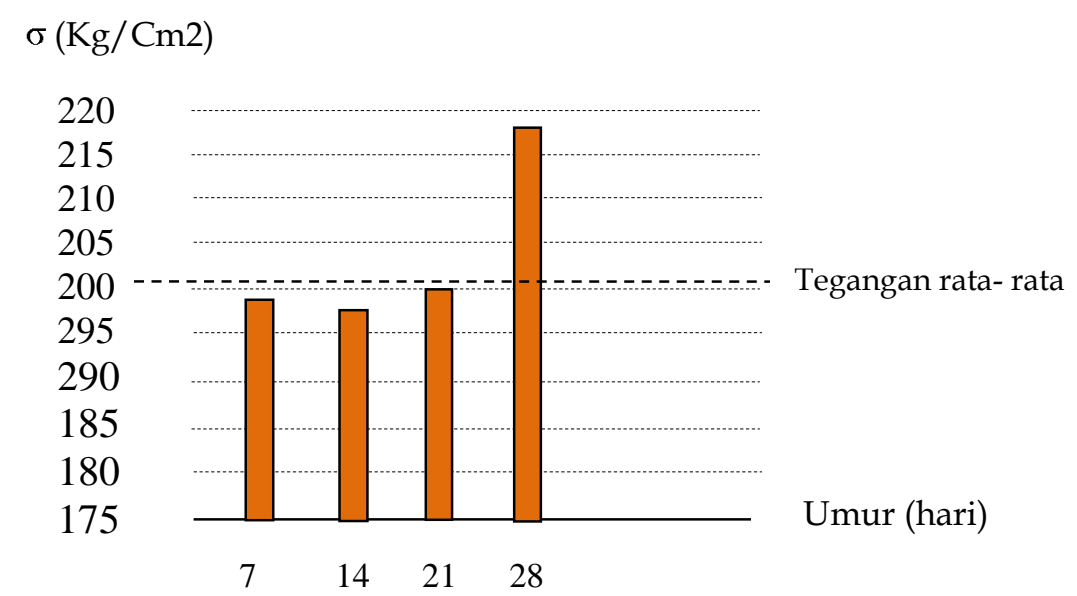

Gambar 8. Diagram Hasil Uji Kubus Beton Job Mixdesing

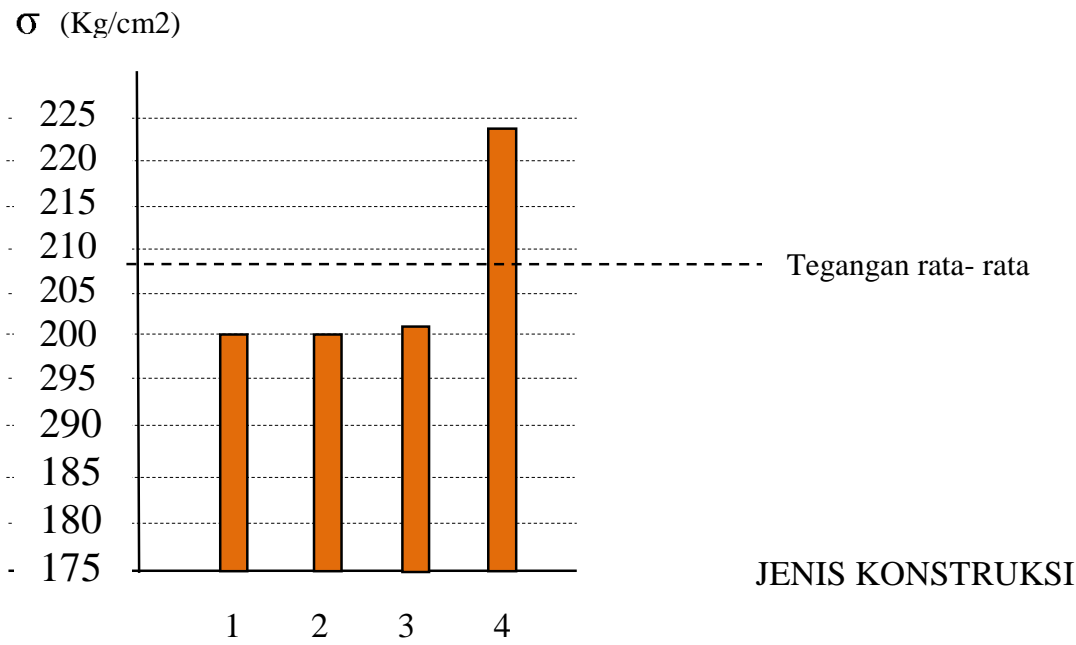

Gambar 9. Diagram Hasil Pengujian Beton Konstruksi Gedung dengan Metode Uji Tekan Presure Test Conreate

Dari hasil pengujian fisik bahan terhadap agregat kasar (batu pecah) adalah sebagai berikut:
- Berat jenis bolk/ oven pasir $\quad=2,61$

- Berat jenis SSD = $=2,63$

- Berat jenis AAP $\quad=2,64$

- Penyerapan $=0,51$ 
- Berat isi $\quad=1,49 \mathrm{~kg} / \mathrm{liter}$

$\sigma(\mathrm{Kg} / \mathrm{cm} 2)$

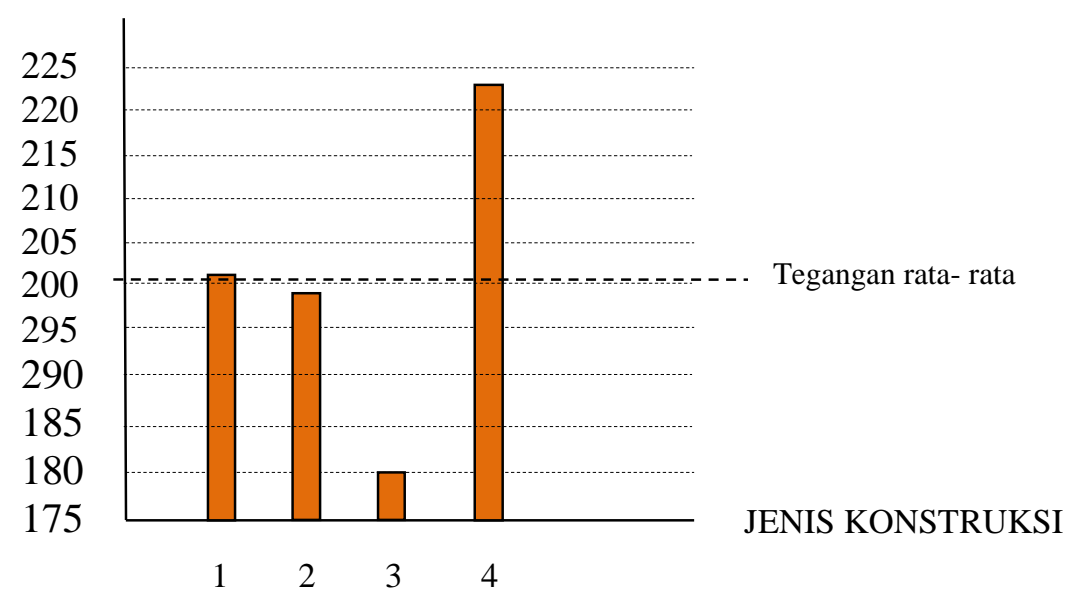

\section{Gambar 10. Diagram Hasil Pengujian Tekan Beton Konstruksi Gedung dengan Metode Uji Hammer Test Conreate}

Tabel 1. Rekapitulasi Hasil pengujian Laboratorium

\begin{tabular}{clccc}
\multirow{2}{*}{ No. } & \multirow{2}{*}{ Jenis Pengujian } & Satuan & Agregat Halus & Agregat Kasar \\
\cline { 4 - 5 } & & & Zone 1 & - \\
2 & Analisa Saringan & $\mathrm{mm}$ & - & 40.0 \\
3 & Besar Butir Maksimum & & 2.63 & 2.63 \\
4 & Penyerapan Air & $\%$ & 0.51 & 0.30 \\
5 & Berat Isi Effektif & $\mathrm{gr} / \mathrm{cm}^{3}$ & 1.49 & 1.49 \\
\hline
\end{tabular}

Sumber: Hasil Analisa Laboratorium

Tabel 2. Komposisi Campuran Beton Dalam Satuan Berat

\begin{tabular}{|c|c|c|c|}
\hline No & Uraian & Satuan & Berat \\
\hline 1 & Semen & $\mathrm{Kg}$ & 351.85 \\
\hline 2 & Air & $\mathrm{Kg}$ & 142.00 \\
\hline 3 & Agregat Halus (Kondisi Ssd) & $\mathrm{Kg}$ & 780.42 \\
\hline 4 & Agregat Kasar (Kondisi Ssd) & $\mathrm{Kg}$ & 1077.73 \\
\hline
\end{tabular}

Sumber: Hasil Perhitungan

Tabel 3. Komposisi Campuran Beton Dalam Satuan Perbandingan Kali

\begin{tabular}{lccccc}
\hline $\begin{array}{c}\text { Bahan } \\
\text { Campuran }\end{array}$ & $\begin{array}{c}\text { Berat } \\
(\text { Kg) }\end{array}$ & B. Isi & $\begin{array}{c}\text { Volume } \\
\text { Cm3 }\end{array}$ & $\begin{array}{c}\text { Volume } \\
\text { Dolak Cm3 }\end{array}$ & $\begin{array}{c}\text { Jumlah } \\
\text { Kali }\end{array}$ \\
\hline Semen & 50 & 1.25 & 40 & 50 & 1 \\
Pasir & 110.90 & 1.49 & 74.19 & 38880 & 2 \\
Batu Pecah & 153.15 & 1.49 & 102.8 & 38880 & 3 \\
Air & 20.23 & 1.00 & 20.23 & Kap. 5 liter & 4 \\
\hline
\end{tabular}

Sumber: Hasil Perhitungan

Tabel 4. Hasil Pengujian Uji Kubus Beton (Job Mixdesign) dengan Metode Uji Tekan Presure Test Conreate

\begin{tabular}{llccc}
\hline No & Uraian & $\begin{array}{c}\text { Umur } \\
(\text { Hari) }\end{array}$ & $\begin{array}{c}\text { Kuat Tekan } \\
(\text { Kg/Cm2) }\end{array}$ & $\begin{array}{c}\text { Nilai Kuat Tekan Rata- } \\
\text { Rata (Kg/Cm2) }\end{array}$ \\
\hline 1 & Uji Kubus Beton & 7 & 198.0 & 201.18 \\
2 & Uji Kubus Beton & 14 & 189.9 & \\
3 & Uji Kubus Beton & 21 & 200.695 & \\
4 & Uji Kubus Beton & 28 & 218.391 & \\
\hline
\end{tabular}

Sumber: Hasil Perhitungan 
Tabel 5. Hasil Perhitungan Pengujian Beton dengan Metode Uji Tekan Presure Test Conreate

\begin{tabular}{llccc}
\hline No & \multicolumn{1}{c}{$\begin{array}{c}\text { Uraian } \\
\text { Kuat Tekan } \\
(\mathbf{K g} / \mathbf{C m} \mathbf{2})\end{array}$} & $\begin{array}{c}\text { Nilai Kuat Tekan Rata- } \\
\text { Rata } \mathbf{( K g / C m 2 )}\end{array}$ \\
\hline 1 & Struktur Pondasi & 28 & 200.761 & \\
2 & Struktur Balok Sloop & 28 & 200.761 & 207.34 \\
3 & Struktur Kolom & 28 & 203.239 & \\
4 & Balok Dan Lantai & 28 & 224.976 & \\
\hline Sumber: & Hasil Perhitungan & &
\end{tabular}

Tabel 6. Data Hasil Pengukuran Pengujian menggunakan Hammer test Concreate

\begin{tabular}{|c|c|c|c|c|c|c|c|c|c|c|}
\hline \multirow{2}{*}{$\begin{array}{c}\text { No. } \\
\text { Titik } \\
\text { Sample }\end{array}$} & \multicolumn{3}{|c|}{$\begin{array}{c}\text { Rebound Value } \\
\text { (R) }\end{array}$} & \multirow{2}{*}{$\begin{array}{c}\text { R } \\
\text { Average }\end{array}$} & \multirow{2}{*}{$\begin{array}{c}\text { Impact } \\
\text { Angle } \\
\text { (A) }\end{array}$} & \multirow{2}{*}{$\Delta \mathbf{r}$} & \multirow{2}{*}{$\begin{array}{c}\text { Srandart } \\
\text { Value } \\
\left(\mathbf{R}_{\mathbf{0}}\right)\end{array}$} & \multirow{2}{*}{$\begin{array}{c}\text { Coef.Of } \\
\text { Concreate } \\
\text { Age }(\square \mathrm{M})\end{array}$} & \multirow{2}{*}{$\begin{array}{c}\text { Comp. } \\
\text { Stranght } \\
(\mathrm{F}) \\
\left.\mathrm{Kg} / \mathrm{Cm}^{2}\right) \\
\end{array}$} & \multirow{2}{*}{$\begin{array}{c}\text { Nila Rata } \\
\text { Rata Kuat } \\
\text { Tekan } \\
\left(\mathrm{Kg} / \mathrm{Cm}^{2}\right)\end{array}$} \\
\hline & 1 & 2 & 3 & & & & & & & \\
\hline \multirow[t]{3}{*}{ Pondasi } & 20 & 20 & 30 & & & & & & & \\
\hline & 28 & 30 & 28 & 25.6 & $-90^{\circ}$ & 4.20 & 29.8 & 1.00 & 202.82 & \\
\hline & 30 & 22 & 22 & & & & & & & \\
\hline Balok & 24 & 30 & 30 & & & & & & & \\
\hline \multirow[t]{2}{*}{ Sloop } & 28 & 28 & 32 & 29.3 & $0^{\circ}$ & 0.00 & 29.3 & 1.00 & 197.33 & 200.87 \\
\hline & 30 & 32 & 28 & & & & & & & \\
\hline \multirow[t]{3}{*}{ Kolom } & 28 & 26 & 30 & & & & & & & \\
\hline & 28 & 26 & 28 & 28.0 & $0^{\circ}$ & 0.00 & 28.0 & 1.00 & 180.0 & \\
\hline & 30 & 28 & 28 & & & & & & & \\
\hline Balok & 28 & 28 & 28 & & & & & & & \\
\hline \multirow[t]{2}{*}{ Lantai } & 26 & 32 & 24 & 27.3 & $-90^{\circ}$ & 4.00 & 31.3 & 1.00 & 223.33 & \\
\hline & 26 & 28 & 25 & & & & & & & \\
\hline
\end{tabular}

Sumber: Hasil Perhitungan

Tabel 7. Hasil Uji Kubus Beton Job Mixdesing

\begin{tabular}{llccc}
\hline No & Uraian & $\begin{array}{c}\text { Umur } \\
\text { (Hari) }\end{array}$ & $\begin{array}{c}\text { Kuat Tekan } \\
(\mathbf{K g} / \mathbf{C m} \mathbf{2})\end{array}$ & $\begin{array}{c}\text { Nilai Kuat Tekan Rata- } \\
\text { Rata (Kg/Cm2) }\end{array}$ \\
\hline 1 & Uji Kubus Beton & 7 & 198.0 & 201.18 \\
2 & Uji Kubus Beton & 14 & 189.9 & \\
3 & Uji Kubus Beton & 21 & 200.695 & \\
4 & Uji Kubus Beton & 28 & 218.391 & \\
\hline Sumber & Hasil Perhitungan & &
\end{tabular}

Sumber: Hasil Perhitungan

Tabel 8. Hasil Pengujian Beton Konstruksi Gedung dengan Metode Uji Tekan Presure Test Conreate

\begin{tabular}{clccc}
\hline No & \multicolumn{1}{c}{ Uraian } & $\begin{array}{c}\text { Umur } \\
(\text { Hari) }\end{array}$ & $\begin{array}{c}\text { Kuat Tekan } \\
(\text { Kg/Cm2) }\end{array}$ & $\begin{array}{c}\text { Nilai Kuat Tekan Rata- } \\
\text { Rata }(\text { Kg/Cm2) }\end{array}$ \\
\hline 1 & Struktur Pondasi & 28 & 200.761 & $\mathbf{2 0 7 . 3 4}$ \\
2 & Struktur Balok Sloop & 28 & 200.761 & \\
3 & Struktur Kolom & 28 & 203.239 & \\
4 & Balok Dan Lantai & 28 & 224.976 & \\
\hline
\end{tabular}

Sumber: Hasil Perhitungan

Tabel 9. Hasil Pengujian Tekan Beton Konstruksi Gedung dengan Metode Uji Hammer Test Conreate

\begin{tabular}{clccc}
\hline No & \multicolumn{1}{c}{ Uraian } & $\begin{array}{c}\text { Umur } \\
(\text { Hari })\end{array}$ & $\begin{array}{c}\text { Kuat Tekan } \\
(\mathbf{K g} / \mathbf{C m})\end{array}$ & $\begin{array}{c}\text { Nilai Kuat Tekan Rata- } \\
\text { Rata }(\mathbf{K g} / \mathbf{C m})\end{array}$ \\
\hline 1 & Struktur Pondasi & 28 & 202.82 & $\mathbf{2 0 0 . 8 7}$ \\
2 & Struktur Balok Sloop & 28 & 197.33 & \\
3 & Struktur Kolom & 28 & 180.0 & 223.33 \\
4 & Balok Dan Lantai & 28 &
\end{tabular}


Tabel 10. Perbandingan Nilai Hasil Uji Tekan menggunakan 2 Metode Pengujian

\begin{tabular}{llcccc}
\hline No & \multicolumn{1}{c}{ Uraian } & $\begin{array}{c}\text { Umur } \\
\text { (Hari) }\end{array}$ & $\begin{array}{c}\text { Hasil Uji Presure Test } \\
\text { Conreate } \\
\text { Kuat Tekan } \\
(\mathbf{K g} / \mathbf{C m} 2)\end{array}$ & $\begin{array}{c}\text { Hasil Uji Hammer } \\
\text { Test Conreate } \\
\text { Kuat Tekan } \\
\text { (Kg/Cm2) }\end{array}$ & $\begin{array}{c}\text { Persen Selisih } \\
\text { Nilai Uji Tekan }\end{array}$ \\
\hline 1 & Str. Pondasi & 28 & 200.761 & 202.82 & $101.03 \%$ \\
2 & Str. Balok Sloop & 28 & 200.761 & 197.33 & $98.29 \%$ \\
3 & Str. Kolom & 28 & 203.239 & 180.0 & $88.56 \%$ \\
4 & Balok Dan Lantai & 28 & 224.976 & 223.33 & $99.27 \%$ \\
A & $\quad$ & $\mathbf{2 0 7 . 3 4}$ & $\mathbf{2 0 0 . 8 7}$ & $3.12 \%$ \\
\hline
\end{tabular}

Sumber: Hasil Perhitungan

Dari beberapa data di atas maka didapat hasil Jobmix design conreate adalah pada tabel 2. Setelah didapat hasil nilai jobmix design beton maka didapat proporsi campuran dalam bentuk takaran, baik dalam jumlah satuan berat maupun dalam jumlah satuan kubikasi maupun berat. Kemudian proporsi campuran tadi diaduk menjadi beton segar. Kemudian buat dan siapkan cetakan kubus dari baja (cetakan baja disiapkan dari alat laboratorium sebagai fasiltas Laboratorium Jurusan Teknik Sipil Dan Perencanaan. Lakukan pengecoran dan pemadatan serta perataan pada pembuatan benda uji kubus. Lakukan perawatan dengan cara beton umur 1 hari bongkar dari cetakan kemudian lakukan perendaman selama selama 7 hari.

Pekerjaan selanjutnya adalah membuat benda uji struktur dilapangan. Pembuatan benda uji struktur dilapangan adalah dengan membuat struktur beton bertulang dengan ukuran bangunan $140 \mathrm{~cm} \times 240 \mathrm{~cm}$. Tinggi bangunan $140 \mathrm{~cm}$ dengan pondasi beton bertulang, balok sloop, kolom, balok dan lantai dak. Konstruksi beton bertulang menggunakan baja U-24 dengan tulangan pokok $\varnothing 10 \mathrm{~mm}$ dan sengkang Ø8-150 mm. Gambar konstruksi dapat dilihat pada gambar 3.

Pembuatan Pengujian benda uji untuk diuji dengan dua alat uji yaitu presure test concreate dengan hummer test conreate. Metede pengambilan benda uji untuk kubus test diambil pada saat pengecoran konstruksi bangunan gedung. Sebelum dilakukan pengecoran bangunan adukan beton segar masing masing diambil tiga buah benda uji kubus beton. Ada empat jenis benda uji kubus beton yaitu; tiga buah benda uji kubus beton pada saat pengecoran pelat pondasi, tiga buah benda uji pada saat pengecoran balok sloop, tiga buah benda uji kubus beton pada saat pengecoran kolom struktur, tiga buah benda uji kubus beton pada saat pengeoran balok dan lantai dak. Jumlah benda uji ada 12 buah kubus beton ukuran $15 \mathrm{~cm} \times 15 \mathrm{~cm} \times 15 \mathrm{~cm}$ dengan mutu beton $\mathrm{K}-200 \mathrm{~kg} / \mathrm{cm}^{2}$. Masing kubus diberi tanda dan tanggal pengecoran.

Perawatan benda uji untuk kubus beton dilakukan dengan perendaman di dalam bejana minimal selama tujuh hari setelah pembongkaran mal. Untuk perawatan konstruksi bangunan benton adalah pada saat selesai pengecoran ditutup dengan plastic beton. Pada umur satu hari permukaan terus dilakukan penyiraman dengan air.

\section{HASIL}

Pengujian benda uji menggunakan dua jenis alat uji adalah sebagai berikut, yaitu alat uji tekan presure test concreate dan hammert test concrete.

Sesi pengujian benda benda uji kubus beton menggunakan alat uji tekan presure test concreate dilakukan beton berumur tujuh hari, 21 hari dan 28 hari. Hasil uji benda uji data dilihat pada tabel 1 . 


$$
\begin{aligned}
& S D=\sqrt{\sum_{1}^{n} \frac{\left(\sigma b^{\prime}-\sigma_{b m}\right)^{2}}{n-1}} \sigma_{b m}{ }^{\prime}=\sum_{1}^{n} \frac{\sigma b^{\prime}}{n} \\
& \sigma_{\mathrm{bk}}{ }^{\prime}=\sigma_{\mathrm{bm}}{ }^{\prime}-\frac{t i x \mathrm{SD}}{\sqrt{\mathrm{n}}}
\end{aligned}
$$

Sedangkan hasil pengujian beton mutu beton $\mathrm{K}-200 \mathrm{Kg} / \mathrm{cm} 2$ yang diuji meggunakan alat tekan beton hummer test concrete. Pengujian kuat tekan beton menggunakan uji tekan hummer test conreate diuji pada umur beton mencapai kekerasan $100 \%$ atau 28 hari. Pengujia kuat tekan beton dimabil mulai dari pelat pondasi, balok sloop, kolom, balok dan lantai. Pada setiap permukaan diambil 9 titik kemudian nilainnya dirata-ratakan.

Analisa Hasil Pengukuran. Dari hasil pengujian baik dari pengujian fisik bahan/material beton maupun pengujian hasil kuat tekan beton maka dapat kami sajikan dalam bentuk diagram batang, seperti gambar 2.

Sebagaimana yang menjadi tujuan utama dalam penelitian ini adalah untuk mencari nilai perbandingan antara dua metode yang diperlukan yaitu pengujian uji tekan beton menggunakan metode presure test concreate dan pengujian beton dengan pengujian menggunakan hammer test conreate. Perbandingan ini dibandingkan dengan uji kubus beton dimana sample material untuk benda uji diambil dari bahan beton segar pada saat akan dilakukan pengecoran konstruksi, yaitu sampel benda uji pondasi, balok sloop, kolom dan balok serta lantai. Mutu beton yang digunakan adalah mutu beton $\mathrm{K}-200 \mathrm{~kg} / \mathrm{cm}$. Benda uji di uji pada saat beton berumur 28 hari (beton kering 100\%). Pengujian menggunakan metode hummert test concreate diuji untuk seluruh konstruksi dari kosntruksi pondasi, balok, kolom balok dan lantai. Pengujian dilaksanakan pada saat beton berumur 28 hari (umur beton mencapai 100\% kering).

Dari hasil kedua metode pengujian ini didapatkan hasil pengujian terhadap kuat tekan beton terlihat pada tabel 10 .

\section{SIMPULAN}

Berdasarkan uraian dari langkah/metode penelitian yang telah dilaksanakan, dan berdasarkan dari tujuan awal penelitian maka dapat kami simpulkan.

Hasil job mix design beton untuk mutu K$200 \mathrm{Kg} / \mathrm{cm}^{2}$, maka didapat campuran komposisi beton setipa $\mathrm{m}^{3}$ yaitu; semen sebanyak $351,85 \mathrm{~kg}$, pasir sebanyak $780,42 \mathrm{~kg}$, batu pecah sebanyak $1077,73 \mathrm{~kg}$, sedangkan air sebanyak 20,23liter air.

Pembuatan benda uji kubus beton untuk uji beton hasil job mix design ukuran $15 \mathrm{~cm} \mathrm{x}$ $15 \mathrm{~cm} \times 15 \mathrm{~cm}$ dibuat sebanyak 12 buah, pembuatan benda uji kubus beton ukuran $15 \mathrm{~cm}$ $\times 15 \mathrm{~cm} \times 15 \mathrm{~cm}$ untuk pengujian struktur beton dibuat sebanyak 12 buah.

Pembuatan benda uji untuk konstruksi bangunan gedung dibuat sruktur pondasi, struktur balok sloop, struktur kolom dan struktur balok dan lantai dengan mutu beton $\mathrm{K}$ $200 \mathrm{Kg} / \mathrm{cm}^{2}$.

Hasil pengujian uji tekan dari masing benda uji yaitu; hasil uji jobmixdesign beton didapat nilai kuat tekan beton rata- rata sebesar $207,34 \mathrm{~kg} / \mathrm{cm}^{2}$, hasil pengujian tekan beton terhadap kuat tekan struktur dari struktur pondasi, struktur balok sloop, struktur kolom dan struktur balok lantai kekuatan rata- rata sebesar 200,87 kg/cm². Pengujian kubus beton menggunakan metode pengujian menggunakan alat uji tekan presure test concreate.

Hasil pengujian struktur bangunan gedung terhadap struktur pondasi, balok sloop, kolom dan balok lantai dengan metode pengujian menggunakan hammer test concreate didapat nilai rata- rata sebesar 200.87 $\mathrm{kg} / \mathrm{cm}^{2}$. 
Selisih nilai antara hasil uji menggunakan metode presure test conreate dengan hummert test conreate mempunyai selisih sebesar $3,12 \%$, dimana hasil uji tekan menggunakan presure test concreate lebih besar.

Dari nilai hasil uji tekan dari kedua metode didapat nilai yang hampir sama, walaupun ada sedikit lebih besar pada nilai uji presure test conreate. Oleh karena itu pemeriksanaan menggunakan hummer test concreate dapat dipergunakan dilapangan oleh tin invertigator dalam melakukan tugasnya dalam melaksanakan investigasi lapanagan, dengan menambah sebesar $3,12 \%$ dari nilai yang ada pada saat pemeriksaan.

\section{Saran}

Dari uraian seluruh kegiatan penelitian ada hal-hal yang masih belum dapat terjangkau dalam lingkup penelitian kami sehingga dirasakan penelitian belum terlalu sempurna. Oleh karena itu ada beberapa hal- hal yang perlu kami sarankan adalah sebagai berikut.

Mestinya penelitian terapan ini tidak dilakukan hanya satu kali, mestinya harus berkali kali.

Setiap lokasi, waktu, dan volume benda uji, serta sumber material tentunya akan berpengaruh terhadap hasil uji tersebut.

Untuk tim pemeriksa di lapangan dalam rangka melaksanakan investigasi hasil pekerjaan konstruksi di lapangan yang menggunakan metode pengujian hammer test conreate disarankan dapat menambahkan angka $3,12 \%$ dari nilai yang terbaca dalam hummer tesr conreate.

\section{DAFTAR PUSTAKA}

Antoni, Paul Nugraha. 2007. Teknologi Beton, LPPM Universitas Kristen Indonesia Petra, Surabaya: Penerbit Andi.

Asroni, Ali. 2010, Kolom Pondasi dan Balok T Beton Bertulang, Graha Ilmu, Surakarta.

Asroni, Ali. 2010. Balok Dan Pelat Beton Beton Bertulang, Graha Ilmu, Surakarta.

Murdock, L.J., K.M. Brook. 1999. Bahan dan Praktek Beton, Erlangga, Alih Bahasa Stepanus Hindarko. Jakarta: PT. Glora Aksara Pratama.

Purwono, Rahmad dan Tavio dkk. 2002. Tata Cara Perhitungan Struktur Beton Untuk Bangunan Gedung (SNI 03-2847-2002), Surabaya: ITS Press.

Purwanto, Rahmad., Tavio, Iswandi Imran, I Gusti Putu Raka. 2007. Standar SNI, Tata Cara Perhitungan Struktur Beton. Surabaya: ITS press. 